\title{
Carbohydrate specificity of lectin, purified from the fruiting bodies of Mycena pura /Fr./ Kumm. and its use in histochemical investigation
}

\author{
V.O. Antonyuk ${ }^{1,2}$, A.M. Yastchenko', R.V. Antonyuk ${ }^{2}$, N.O. Ambarova ${ }^{2}$ \\ ${ }^{1}$ Institute of Cell Biology, NAS of Ukraine \\ 14/16 Drahomanov Str., Lviv, Ukraine, 79019 \\ ${ }^{2}$ Danylo GalytskyLviv National Medical University \\ 69, Pekarska Str., Lviv, Ukraine, 79010
}

antonyuk@meduniv.lviv.ua

\begin{abstract}
Aim. The purpose of this investigation was to research carbohydrate specificity of a new lectin from fruiting body of Mycena pura and possibilities of its application in histochemical studies. Methods. The lectin has been purified by affinity chromatography on "ovomucine». The lectin carbohydrate specificity has been determined by a reaction of inhibiting haemagglutination by haptens. Histological materials were fixed in 4 $\%$ neutral formalin solution. Alkaline phosphatase was revealed in the cryostat unfixed microscopical sections. Results. The lectin yield from fresh fruit bodies of raw material was $9 \mathrm{mg} / \mathrm{kg}$. Mol. mass of the lectin is $40 \mathrm{kDa}$. The lectin poorly interacted with D-glucose and D-mannose in contrast to lectins from Pisum sativum and Leucojum vernum. The peculiarity of this lectin is its strong interaction with alkaline phosphatase, the highest among twenty tested lectins. However, the receptors for Mycena lectin binding in mammalian tissues are not limited by this enzyme being presented also by glycoconjugates of another structure, as it was shown for fetus calf small intestine and kidney of rat. Conclusions. An important role in the lectin interaction with glycoproteins probably belongs to the disaccharide links of

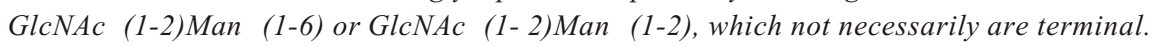

Keyword: Mycena pura, lectins, histochemistry, alkaline phosphatase.

Introduction. Lectins are a group of proteins of non-immune origin, notable for features of reversible and selective binding to carbohydrates and carbohydrate determinants of biopolymers, without changing their covalent structure [1]. Most living organisms have been found to contain lectins, performing various func-

(C) Institute of Molecular Biology and Genetics NAS of Ukraine, 2009 tions, based on the processes of recognizing carbohydrate structures in macromolecules. The end of the 1980's witnessed the discovery of the fact that the integral complex of different lectins functions in both vegetable and animal organisms. Acting as companions, lectins regulate the intracellular glycoprotein movement. For instance, calnexin (membrane-bound lectin of endoplasmatic reticulum) functions simultaneously with its soluble analogue calreticulin as a part of the 
system of regulating glycoprotein quality. Galectins (galactose-specific lectins of animal origin) act as modulators of interactions between the substrate and the cell, and are required for normal functioning of the programme of differentiation and growth of all multicellular animal organisms. They are capable of stimulating cell proliferation and apoptosis, and participate in organomorphogenesis, metastasis of tumour cells, immune response and inflammatory processes as well as in recognition of extracellular matrix [2]. The role of lectins in mycorrhize formation between the fungal hyphae and coniferous trees was studied for true fungi, Basidiomycetes, in particular [3].

To date lectins have been widely used in histochemistry investigations on the determination of carbohydrate determinants on the cell surface. The lectins (labelled by peroxidase, colloidal gold, fluorochrome), obtained from different living organisms, are used for the purposes of the above mentioned investigations. The study on phylogenetically remote organisms enhances the probability of determining lectins of rare carbohydrate specificity which would open new opportunities for histochemistry investigations. Therefore, the search for, obtaining and analysis of carbohydrate specificity of new lectins is an important task.

While studying the fruit bodies of basidium fungi of Mycena pura /Fr./ Kumm) we have discovered a lectin which has not been described in literature yet, and called it Mycena pura fungus agglutinin (short name - MPFA).

The aim of the current work is to characterize the carbohydrate specificity of the lectin and to analyze the possibilities of its use in histochemical research.

Materials and Methods. The fruit bodies of the Lilac Bell Cap for the purpose of obtaining lectins were collected in Skole district of the Lviv region. They were transported to the laboratory on the same day as collection.

The isolation of lectins from the fruit bodies of the Lilac Bell Cap was performed using the affinity chromatography on ovomucin as the sorbent using a previously described method [4]. The scheme of lectin purification included the extraction of shredded fruit bodies using the buffered physiological solution (BPS), with subsequent acidification to $\mathrm{pH} 4.5$, and reduction of the extract to $\mathrm{pH} 8.4$ with the removal of precipitates formed, precipitation of proteins with ammonium sulphate $(600 \mathrm{~g} / \mathrm{l})$, affinity chromatography on ovomucin, additional purification on DEAE-Toyopearl in $0.1 \mathrm{M}$ phosphate buffer solution, $\mathrm{pH} 7.0$, concentration and and freeze-drying of the purified preparation.

The preparation purity was estimated using disk-electrophoresis in $10 \%$ polyacrylamide gel (PAAG) in alkaline buffer system (pH 8.6). After the electrophoresis in two parallel tubes, the gel in one of them was stained with coomassie R-250, the gel from the other was cut in $5 \mathrm{~mm}$ pieces and homogenized with 0.25 BPS, pH 7.4 with subsequent determination of hemagglutination titre in the extracts obtained.

Minimal molecular mass $\left(M_{r}\right)$ of polypeptide chains of the lectin was determined using electrophoresis in the PAAG gradient concentration (10-15\%) with $0.1 \%$ sodium dodecyl sulphate [5]. Ovolysozyme $\left(M_{r}=\right.$ $14.3 \mathrm{kDa})$, lectin from lentil seeds $\left(M_{r}=5.7+17.5\right.$ $\mathrm{kDa})$, lectin of edible snail $\left(M_{r}=26 \mathrm{kDa}, 78 \mathrm{kDa}\right)$, ovalbumin $\left(M_{r}=44 \mathrm{kDa}\right)$ were used as standards.

The carbohydrate specificity of lectins was determined using the reaction of hemagglutination inhibition with carbohydrates and glycoproteins. The stepwise dilution of the carbohydrate was used to determine its minimal concentration, which inhibits the activity of lectin with 1:4 titre completely [6].

The following substances were used to characterize the carbohydrate specificity of the lectin: D-glucose, D-fructose, D-galactose, sucrose, maltose, lactose (Soyuzchimreactiv, RF), raffinose (Fluka, Switzerland), $\alpha$ - and $\beta$-methyl-D-galactosides, L-rhamnose, cellobiose, N-acetyl-D-galactopyranoside and N-acetyl-D-glucopyranoside (Chemapol, Chech Republic), D-mannose, D-turanose, L-ribose (Bratislava Chemical Institute, Slovakia), melibiose, $\alpha$-methyl-Dmannoside, L-fucose (Koch Light, UK).

The interaction with glycoproteins and polysaccharides was defined using the glycogen of porcine liver, ovomucoid, thrice re-crystallized ovalbumin (Biolar, Latvia), and yeast mannan [7]. Group-specific substances $\mathrm{H}, \mathrm{A}$, and B were isolated from the cyst liquid, obtained after the surgery on the ovaries of patients' who have corresponding blood groups. The mentioned substances were purified by the method, described in [1]. The purified transferrin and orozomucoid were kindly provided by Professor M.D. Lutsyk. 


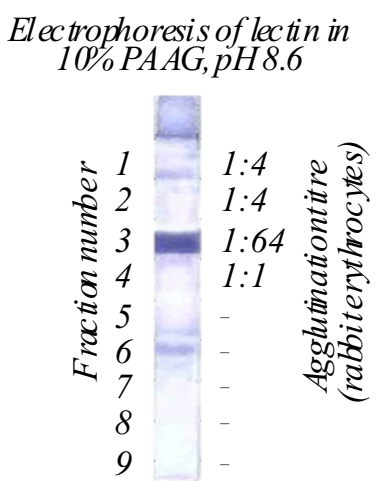

Fig. 1. Electrophoretic purity of the lectin from Mycena pura fruit bodies

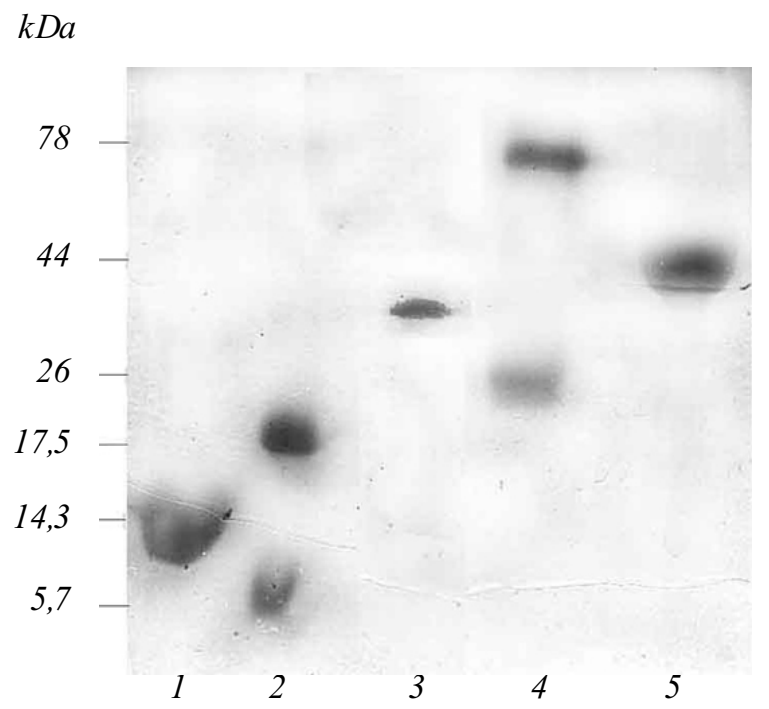

Fig. 2. Electrophoresis of obtained Mycena lectin (MPFA) and proteins with known molecular mass in PAAG concentration gradient $(10-15 \%)$ with $0.1 \%$ sodium dodecyl sulphate: 1 lysozyme; 2 - LCA; 3 - MPFA; 4 - HPA; 5 - ovalbumin

The conjugates of lectins with horseradish peroxidase were prepared by the method, described in [8].

Alkaline phosphatase activity was determined in cryostat-unfixed microscopic sections using a method originally intended for cytochemical research [9] and adapted by us for the small intestinal tissue of 6-month-old calf fetuses and rat kidney tissue. The incubation solution contained $10 \mathrm{mg}$ naphtol-AS-MX phosphate (Sigma, USA), $10 \mathrm{mg}$ fast blue PP (Fluka, Germany) in $10 \mathrm{ml} 0.08 \mathrm{M}$ tris-HCl buffer solution, $\mathrm{pH}$ 9.2, the incubation was performed using the microscope control to observe the appearance of blue granules (5-10 min), then the sections were washed with the distilled water and put into gelatin-glycerol. At the same time the sections were stained with the conjugate of horseradish peroxidase-lectin of Mycena pura /Fr./ Kumm.

The histological materials were fixated in $4 \%$ neutral formalin in order to investigate the interaction of lectins, stained with peroxidase, and the preparations of rat colon. The 5-7 $\mu \mathrm{m}$ sections were stained with hematoxylin and eosin for general morphology [10].

The microscopy and photography of the preparations were performed using the photomicroscope MBI 15-2.

Results and Discussion. From $1 \mathrm{~kg}$ of Mycena pura fresh fruit bodies, $9 \mathrm{mg}$ of the purified lectin was obtained. This is about $59 \%$ of the theoretical output based on calculation of the activity in an initial extract.

The intensity of stained stripes and the data of the agglutination (performed in the parallel gel tube) during electrophoresis in 10\% PAAG in an alkaline buffer system ( $\mathrm{pH}$ 8.6) allow the conclusion that the purified preparation contains about $90 \%$ lectin (Fig.1). This amount is sufficient to perform the majority of histochemical investigations.

An area of $M_{r} \approx 40 \mathrm{kDa}$ was observed during electrophoresis in $15 \%$ PAAG in the presence of $0.1 \mathrm{DS}-\mathrm{Na}$ purified lectin of M. pura (Fig.2).

The agglutination capacity of the purified Mycena lectin relative to erythrocytes of humans and animals is presented in Table 1. The specificity of Mycena lectin is its capacity of hemolyzing the erythrocytes of rabbits, humans, and dogs in the concentration of $1 \mathrm{mg} / \mathrm{ml}$ along with agglutination, therefore, it may be considered to be a bifunctional lectin. The hemolysis (not agglutination) is inhibited in the presence of polyethylene glycol with $M_{r}=3000 \mathrm{Da}$, which enables determining both the hemagglutination titre and carbohydrate specificity of the lectin.

The investigation of the interaction of the lectin (MPFA) with carbohydrates revealed that it has rather poor interaction with D-glucose and D-mannose. Therefore, we decided to compare its carbohydrate specificity with that of the lectin of pea (Pisum sativum agglutinin, PSA, Fabaceae family), and the lectin of a snowflake (Leucojus vernus agglutinin, LVA, Amaryllidaceae family), which are the representatives of two different subgroups of D-mannose-specific lectins [11]. 
Table 1

Minimal concentration of purified Mycena lectin which causes the agglutination of erythrocytes

\begin{tabular}{c|c|c|c|c|c|c|c|c}
\hline \multicolumn{7}{c}{ Minimal concentration of purified Mycena lectin, capable of causing the agglutination of erythrocytes, $\mu \mathrm{g} / \mathrm{ml}$} \\
\hline & Humans & Sheep & Goat & Cow & Horse & Rabbit & Dog \\
\hline O (I) & A (II) & B(III) & & & & & \\
\hline 312 & 156 & 312 & 312 & 1250 & 2500 & 39 & 39 \\
\hline
\end{tabular}

Table 2

The interaction of Mycena lectin with some mono- and disaccharides

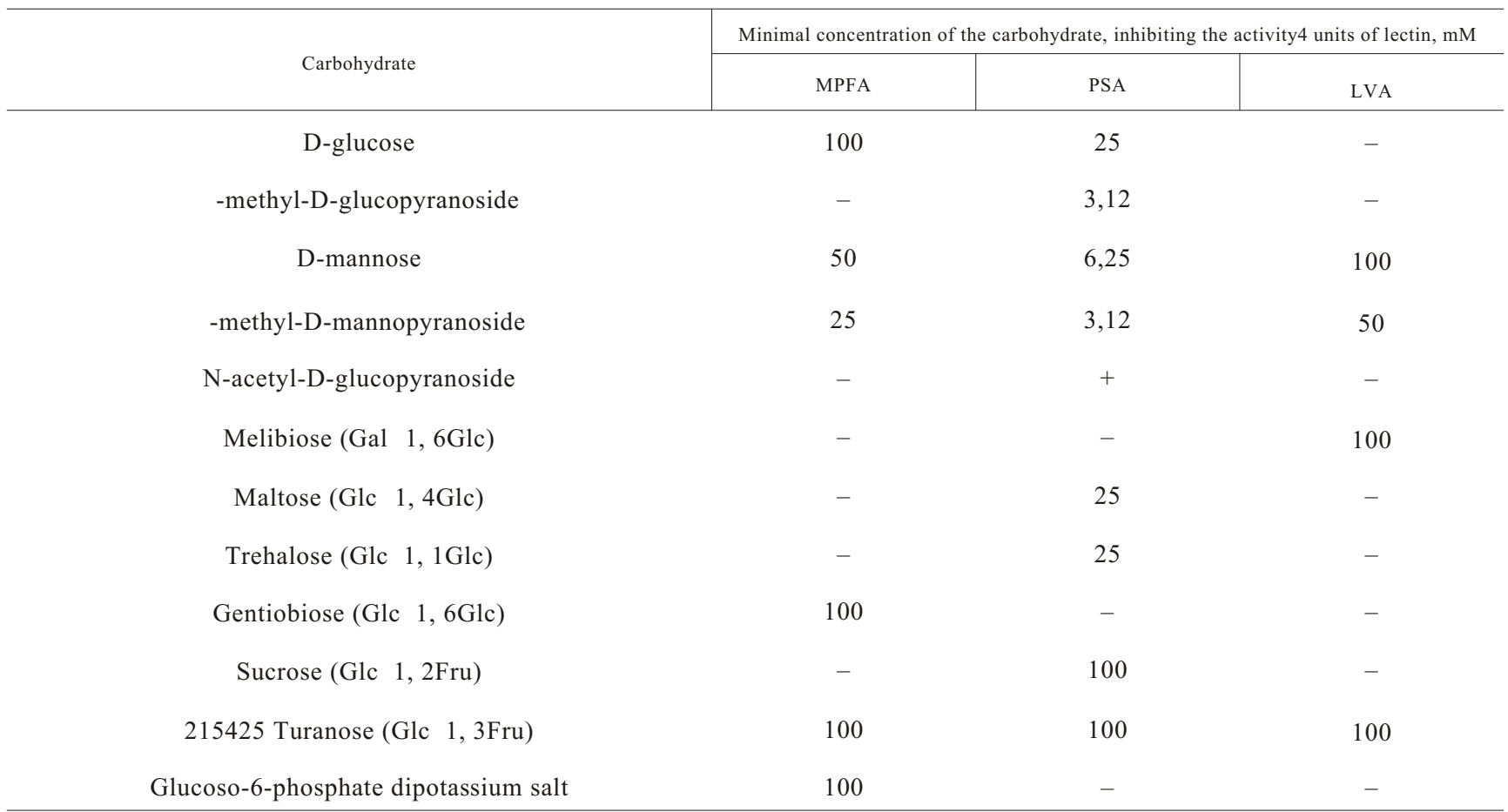

All lectins, as presented in Table 2, do not interact with D-galactose, $\alpha$ - and $\beta$-methyl-D-galactosides, L-rhamnose, cellobiose (Glc $\beta 1, \quad 4 \mathrm{Glc}$ ), $\mathrm{N}$-acetyl-D-galactopyranoside, D-fructose, and L-fucose which are not included into Table.

The three investigated lectins (PSA, LVA and MPFA) have better binding to compound oligosaccharide structures, which are glycoconjugate components. Instead, their interaction with some substances is considerably different. For instance, the yeast mannan interaction with LVA is very strong, PSA - medium, and the Mycena lectin - completely absent. PSA binds strongly to bovine thyroglobulin and sheep submaxillary mucin, while the interaction of LVA and MPFA with the latter is medium. The Mycena lectin strongly interacts with calf intestinal alkaline phosphatase, while PSA has poor interaction with it, and LVA does not interact at all. The abovementioned fact testifies to higher complementarity of the centres of carbohydrate interaction of the Mycena lectin, PSA and LVA towards different carbohydrates of complex and branched structure (Table 3 ).

There are literature data, proving the presence of alkaline phosphatase (E.C.3.1.3.1) in all the tissues and liquids of the organism, except for the vessel walls and hyaline cartilage. This enzyme is abundant in the epithelium of the small intestine wall, flexuous renal tubules, bone tissue, breast glands during lactation, and in leucocytes [12]. Alkaline phosphatase of the calf small intestine is zinc-containing two-chain 
Table 3

Interaction of lectins with polysaccharides and glycoproteins

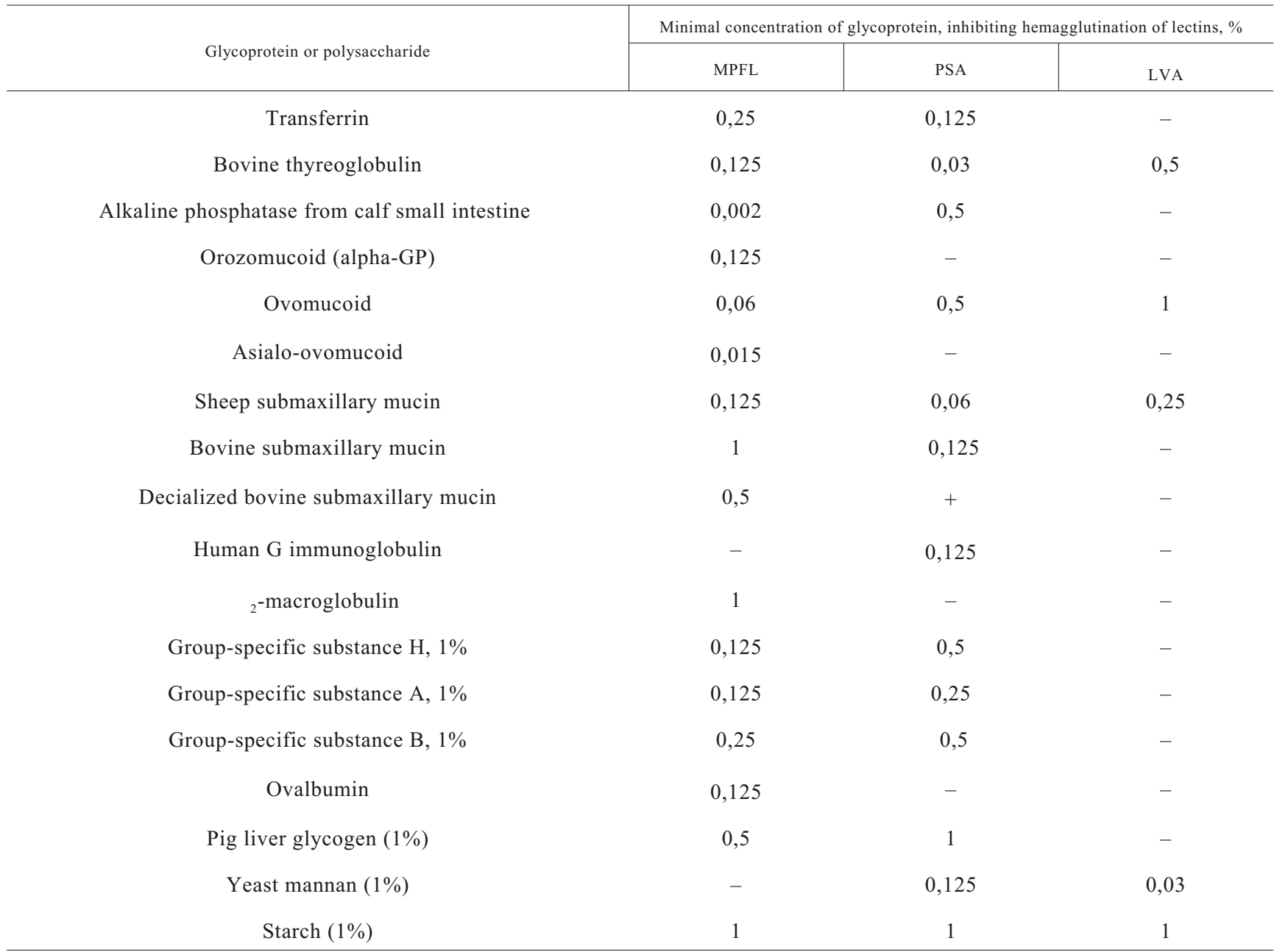

$\mathrm{N}$ o t e. Dash means the absence of interaction in $1 \%$ concentration.
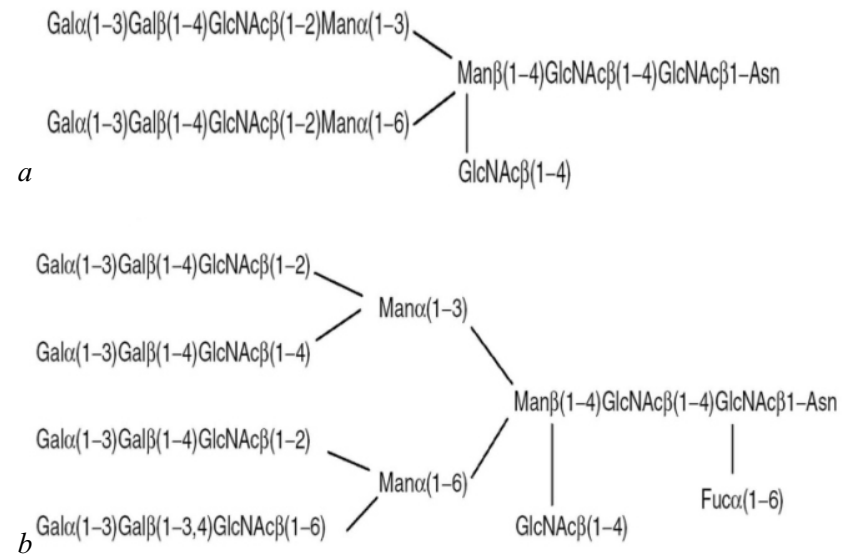

Fig.3. Glycopeptide structure attached to Asp249 (a) and Asp410 (b) of calf small intestinal alkaline phosphatase [5] glycoprotein with $M_{r}=65 \mathrm{kDa}$, that has two sites of glycosylation - near asparagine-249 containing a basic glycosylresidue is with two antennas and contains D-galactose, D-glucosamine, and D-mannose, while glycosylated residue near asparagine-410 is with four antennas and contains L-fucose (Fig.3). Total amount of carbohydrates in the phosphatase is from 8 to $17 \%$ (depending on the type and localization of the enzyme) [13]. The structures of the mentioned enzyme in humans and mammals have some differences, but they are not considerable. Due to a high amount and variety of carbohydrates in the phosphatase one may expect its interaction with many lectins, among which there are some with different carbohydrate specificity. 
Interaction of lectins with alkaline phosphatase of calf small intestine (E.C. 3.1.3.1)

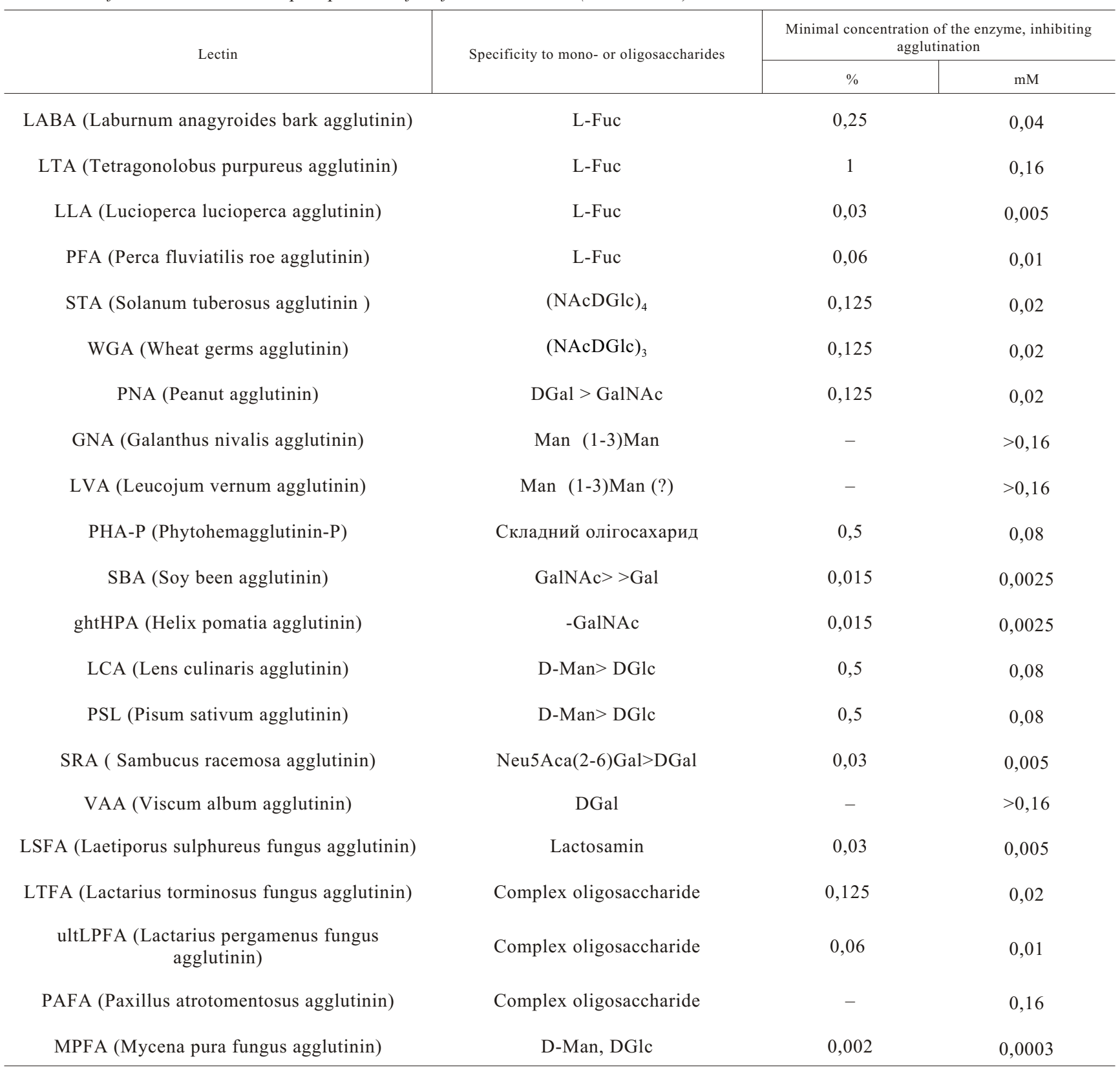

$\mathrm{N}$ o t e. Dash means the absence of interaction in $1 \%$ concentration

Taking the above mentioned into consideration, we have studied the interaction of a purified enzyme with the lectins, which are used in histochemical investigations the most frequently and the lectins, which were first obtained in our laboratory. The results, presented in Table 4, demonstrate that many lectins really bind to the phosphatase, in particular, there were strong interactions with the lectins of soy bean and edible snail, while the alkaline phosphatase was the strongest inhibitor of the activity for Mycena pura lectin. The lectins of Amaryllidaceae family (snowdrop and snowflake) and, unexpectedly, the lectin of mistletoe do not interact with the alkaline phosphatase.

The reaction for alkaline phosphatase performed as a control in non-fixed frozen sections of small intestine of 6-month-old calf foetus demonstrated the presence 


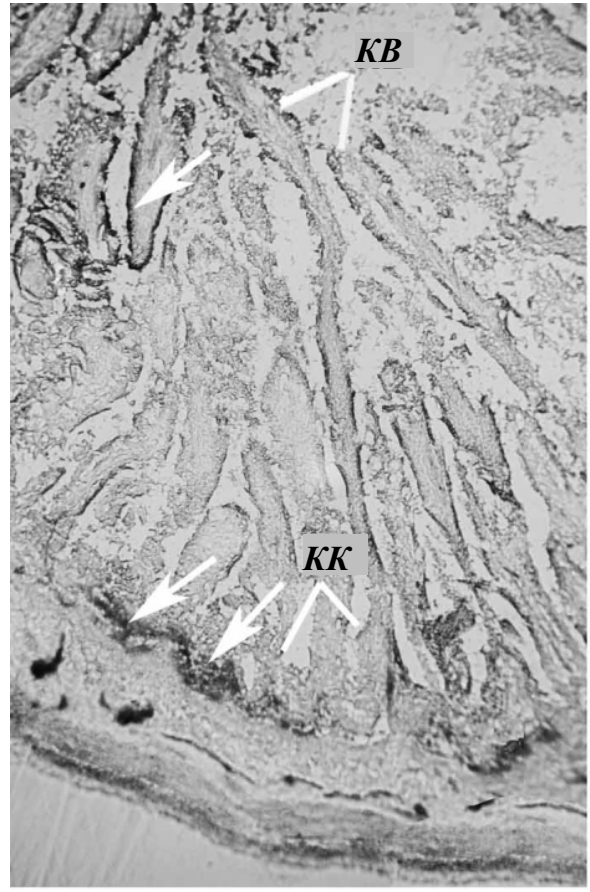

$a$

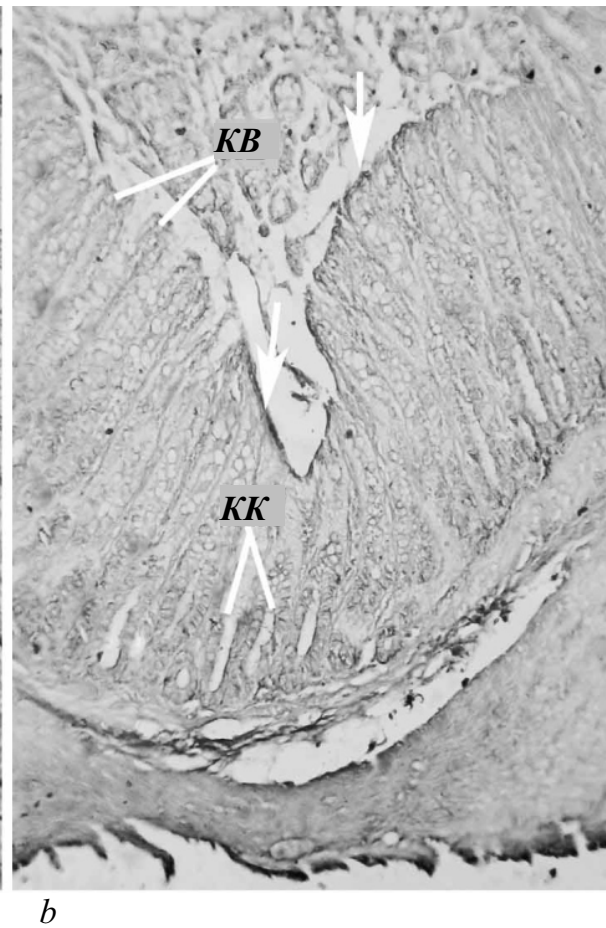

Fig.4. Reaction to alkaline phosphatase (a) and staining with Mycena lectin (b) on the preparation of small intestine of 6-month-old calf foetus (x120); KB villi cells; $K K$ crypt goblet cells Arrows indicate: $a$-places of the most intense reaction to alkaline phosphatase; $b-$ sites of binding of Mycena lectin of the enzyme only in enterocytes with the epithelial plate border of villi and crypts, while the reaction with the stained Mycena lectin on the sections revealed a similar pattern of the interaction with slight differences. The reaction for alkaline phosphatase was more intense in enterocytes of both villi and crypts, while only some enterocytes of crypts reacted to Mycena lectin (Fig.4, $a, b$ ).

Another verification of the assumption regarding the selectivity of Mycena lectin binding to carbohydrate determinants, present in the molecule of alkaline phosphatase, was performed in the tissues of rat kidney, which is rich in various carbohydrate receptors. In this experiment we identified the activity of alkaline phosphatase in the composition of brush border of proximal renal tubules of new-born rats (Fig.5), whereas the receptors of Mycena lectin were localised in the cytoplasm of different populations of nephrocytes with the tendency to accumulating in the apical part and on the luminal surface of the eventual ampoules cells, S-like bodies, and the basic parts of the collapsible kidney channels.

The data obtained may testify to the fact that the action of substrates for binding MPFA lectin is much wider and is not restricted only by the activity of alkaline phosphatase. They may be presented in kidneys by other glycoconjugates of complex structure with terminal determinants DMan/DGlc and DGlcNAc, including glycogen.

To detect these glycoconjugates, lectin binding with carbohydrate receptors was examined using histological preparations with a row of control reactions on microscopic sections of rat small intestine using carbohydrate and glycoprotein inhibitors.

Our assumption on negative results of the control reaction for the determination of probable endogenous peroxidase was proven.

The reaction with the stained Mycena lectin was clearly positive. The presence of $5 \%$ solution of $\alpha$-methyl-D-galactopyranoside, with which the lectin does not interact, did not result in the inhibition of the reaction. The presence of $5 \%$ solution of $\alpha$-methyl-D-mannopyranoside ( $\approx 250 \mathrm{mM}$ solution), with which the lectin interacts, resulted in weaker reaction, but there was no complete inhibition of the reaction. It proves that the abovementioned carbohydrate is a poor inhibitor of Mycena lectin. The presence of $1 \%$ ovalbumin $(\approx 0.23$ millimolar solution or in molar concentration, which is $250: 0.23=1087$-fold less for that of $\alpha$-methyl-D-manopyranoside) weakened the reaction, but its level was approximately equal to that of the presence of $5 \% \quad$ solution of 


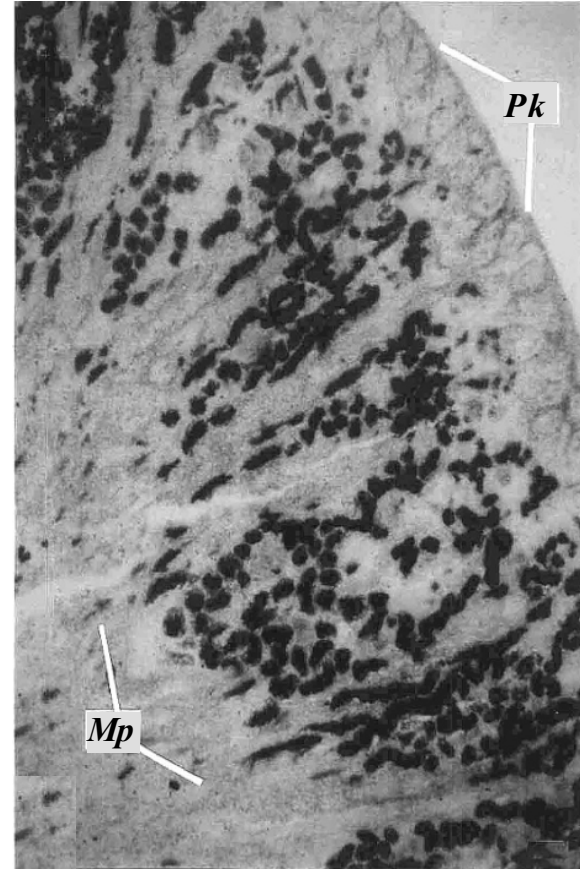

$a$

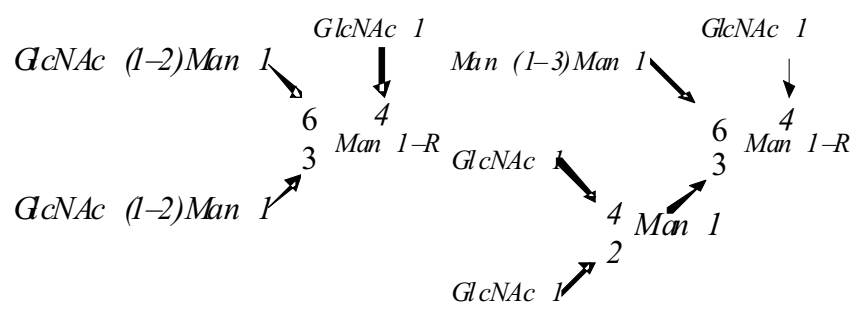

Fig.6. Carbohydrate component of an ovalbumin molecule

$\alpha$-methyl-D-manopyranoside. And only in the presence of $1 \%$ solution of alkaline phosphatase of calf small intestine the reaction was blocked completely. The concentration of the latter is $0.15 \mathrm{mM}$ which is close to the concentration of ovalbumin, but it is approximately 1623 times lower than the molar concentration of $\alpha$-methyl-D-mannopyranoside. One must take into account that, on average, only one-sixth of the alkaline phosphatase molecule is a carbohydrate fragment. In other words, the oligosaccharide chain, isolated in a pure form, may be almost a ten thousand times $(1623.6=9740)$ stronger inhibitor than $\alpha$-methyl-D-mannopyranoside.

Egg albumin, which has a medium MPFA inhibitory activity, consists of $3.2 \%$ carbohydrate that forms three and four antennate glycan links; there can be at least 6 different variants, 2 of which are presented in Fig. 6 [14].
Fig.5. Histotopography of activity of alkaline phosphatase (a) (x60) and receptors of Mycena lectin (b) (x120) in the composition of structural components of new-born rat kidney; $a-$ the activity of alkaline phosphatase is localized in the composition of brush border of proximal and distal tubules (knots, end ampoules and main segments of composite kidney ducts are areactive; $P k$-surface of cortex; $M p$ - medullary substance of the kidney); $b$ - intense reactivity of kidney parenchyma with MPPA lectin $(K l-$ knots, $K a-$ kidney capsule, triangles indicate the ampoules of composite kidney ducts)

The comparison of structures of glycan residues of alkaline phosphatase and ovalbumin demonstrates that the inner part of oligosaccharide chains (disaccharide links GlcNAc $\beta(1-2)$ Man $\alpha(1-6)$ or GlcNAc $\beta(1-2)$ Man $\alpha(1-2))$ is similar for them, while terminal carbohydrates are different. As for alkaline phosphatase, the residues of disaccharides Gal $\alpha(1-3) \mathrm{Gal} \beta(1-4)$, which do not inhibit the interaction of the lectin and carbohydrate, are terminal. It proves that the active centre of Mycena lectin is complementary to complex oligosaccharide structures, probably, branched oligosaccharides of four-antennate type, where disaccharide links GlcNAc $\beta(1-2)$ Man $\alpha(1-6)$ play a significant role in the lectin-carbohydrate interaction.

Because of the presence of alkaline phosphatase in enterocytes of the large and small intestine and interaction with this enzyme of the majority of tested lectins, it is much more informative for study of histological preparations of the colon is the use of lectins that do not interact with alkaline phosphatase.

The lectins of snowflake and snowdrop almost do not interact with histological sections of rat colon. The "multimannose type" oligosaccharides with terminal Mano(1-3)Man-residues are known for the highest inhibition activity for the lectin of the snowdrop. This 
lectin also actively interacts with oligosaccharides, containing branched $\alpha(1-6)$-bound residues of glucose or mannose, but it does not interact with branched residues, containing Gal, GalNAc, and Fuc. The lectin of the snowflake is characterized by similar specificity. Therefore, one can firmly state that there are no such carbohydrate structures in the colon.

Other lectins, used for staining histological structures of the colon, may interact with both alkaline phosphatase and other carbohydrate receptors, thus, their response is ambiguous.

\section{Conclusions.}

1. The investigation of the interaction of the new lectin, purified by us from the fruit bodies of Mycena pura, with carbohydrates and glycoproteins revealed that according to the wide-spread classification of lectins, this lectin may be referred to glucoso-(mannoso-)-specific ones. However, its fine carbohydrate specificity distinguishes it from previously known lectins of legumes and Amaryllidaceae family (the lectins of Pisum sativum and Leucojum vernum). The results of investigation on the binding of the mentioned lectin to glycoproteins allow the assumption that the important part belongs to disaccharide links GlcNAc $\beta(1-2) M a n \alpha(1-6)$ or GlcNAc $\beta(1-2)$ Man $\alpha(1-2)$, while terminal residues of disaccharides Gal $\alpha(1-3)$ Gal $\beta(1-4)$ do not abolish the interaction of the lectin and carbohydrates and, probably, are not significant for this interaction.

2. The distinctive feature of Mycena lectin is its strong interaction with alkaline phosphatase - the relative inhibition of this interaction was found to be the highest among twenty investigated lectins. However, the sensitivity of receptors for binding MPFA lectin in the tissues of mammals is not limited to alkaline phosphatase only, it may be related to other glycoconjugates of complex structure, as it was shown on the example of rat kidney and small intestine of calf foetus.

3. Complete absence of the interaction of the lectins of snowflake and snowdrop with histological structures of the colon testifies to the fact that their composition contains neither oligosaccharide structures of multimannose type with terminal $\operatorname{Man}(\alpha 1-3)$ Man-residues nor oligosaccharides, having branched $\alpha-1-6$ bound residues of glucose or mannose.
4. Due to wide substrate specificity of most lectins in the course of performing histochemical reactions for correct interpretation of the results, obtained while using them, it is necessary to perform additional reactions to reveal specific glycoconjugates and lectin-histochemical reactions in the presence of carbohydrate inhibitors.

\section{В. О. Антонюк, А. М. Ященко, Р. В. Антонюк, Н. О. Амбарова}

Вуглеводна специфічність лектину, одержаного з плодових тіл міцени чистої (Mycena pura /Fr./ Kumm.), та його використання у гістохімічних дослідженнях

\section{Резюме}

Мета. Дослідити вуглеводну специфічність нового лектину 3 плодових тіл гриба М. рига та можливість його використання y гістохімічних дослідженнях. Методи. Лектин одержували афінною хроатографією на сорбенті овомуцині. Вуглеводну специфічність лектинів визначали за допомогою реакції пригнічення гемаглютинації гаптенами. Гістологічні матеріали фіксували у 4 \%-му розчині нейтрального формаліну, а лужну фосфатазу виявляли в кріостатних нефіксованих зрізах. Результати. Вихід лектину із сировини становив 9 мг з 1 кг свіжих плодових тіл. Молекулярна маса лектину дорівнює $\approx 40$ кДа. Лектин мічени слабко зв 'язується з $D$-глюкозою та $D$-манозою на відміну від лектинів Pisum sativum ma Leucojum vernum. Особливістю досліджуваного лектину $\epsilon$ сильна взаємодія з лужною фосфатазою - вона виявилася найвищою серед 20 випробуваних лектинів. Але чутливість рецепторів для зв 'язування лектину міцени у тканинах ссавців циим ферментом не обмежується, вона може поширюватися $i$ на іншиі глікокон'югати складної будови, як ие показано на прикладi тонкої кишки плода теляти $і$ нирки щура. Висновки. У взаємодії лектину з глікопротеїнами, ймовірно, важлива роль

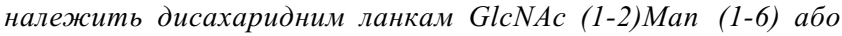
GlcNAcß(1-2)Man $\alpha(1-2)$, які не обов 'язково є термінальними.

Ключові слова: Мічена чиста, лектини, гістохімія, лужна фосфатаза.

\section{В. А. Антонюк, А. М. Ященко, Р. В. Антонюк, Н. О. Амбарова}

Углеводная специфичность лектина, полученного из плодовых тел мицены чистой (Mycena pura /Fr./ Kumm.), и его использование в гистохимических исследованиях

Резюме

Цель. Исследование углеводной специифичности нового лектина из плодовых тел гриба М. рига и возможностей его использования в гистохимических исследованиях. Методы. Лектин получали аффинной хроматографией на сорбенте овомуцине. Углеводную специфичность лектинов определяли с помощью реакиии угнетения гемагглютинации гаптенами. Гистологические материалы фиксировали в $4 \%$-м растворе нейтрального формалина, а шелочную фосфатазу выявляли в криостатных нефиксированных срезах. Результаты. Выход лектина из 
сырья составил 9 мг на 1 кг свежих плодовых тел. Молекулярная масса лектина равна $\approx 40$ кДа. Лектин слабо взаимодейcтвует с D-глюкозой и $D$-маннозой в отличие от лектинов Pisum sativum и Leucojum vernum. Особенностью исследуемого лектина является его сильное взаимодействие со щелочной фосфатазой - оно оказалось наивыстим среди 20 испытанных лектинов. Но чувствительность рецепторов для связывания лектина мицены в тканях млекопитающих этим ферментом не ограничивается, она может распространяться и на другие гликоконъюгаты сложного строения, как это показано на примере тонкой кишки плода теленка и почки крысы. Выводы. Во взаимодействии лектина с гликопротеинами важная роль, вероятно, принадлежит дисахаридним звеньям GlcNAcß(1-

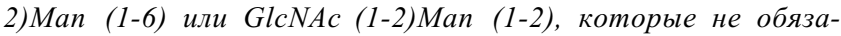
тельно являются терминальными.

Ключевые слова: Мицена чистая, лектины, гистохимия, щелочная фосфатаза.

\section{REFERENCES}

1. Lutsik A. D., Detyuk E. S., Lutsik M. D. Lectin in histochemistry.-Lviv: Lviv Univ. publ., 1989.-144 p.

2. Sharon $N$., Lis $H$. History of lectins: from hemagglutinins to biological recognition molecules // Glycobiology.-2004.-14, N 11.-53R-62R

3. Giollant M., Guillot J., Damez M., Dusser M., Didier P., Didier E.Characterization of a lectin from Lactarius deterrimus. Research on the possible involvement of the fungal lectin in recognition between mushroom and spruce during the early stages of mycorrhize formation // Plant. Physiol.1993.- 101.-P. 513-522.
4. Pat. (Autor's sertificate) No 1554961. Method for obtaining of affinity sorbent for purification of lectin / V. A. Antonyuk // Bull. Izobret. USSR.-1990.-N 13 (In Russ.).

5. Maurer G. Disk-electrophorese--Moscow: Mir, 1971.-102 p.

6. Lutsik M. D., Panasjuk E. N., Antonyuk V. A., Lutsik A. D., Ladnaya $L$. Ya. Method for investigation carbohydrate specificity of lectins (Methodical recommendation).-Lviv, 1983.-20 p.

7. Methods of carbohydrate chemistry / Ed. N. K. Kotchetkov.Moscow: Mir, 1967.-512 p.

8. Antonyuk V. O., Yashtchenko A. M. The lectins conjugation with horseradish peroxydase: improvement of method // Clin. Lab. Diagnostic (Moscow).-1996.-N 3.-P. 51-52.

9. Glusman D. Ph., Sclarenko L. M., Nagornaja V. A., Klumyuk $G$. I. Imunocytochemical tumor diagnostic of haematogenous and lymphoid tissues in children.-Kyiv: DIA, 2005.-P. 178179.

10. Kononsky A. I. Histochemistry.-Kyiv: Vyshcha shkola, 1976. $-280 \mathrm{p}$

11. Antonyuk V. O. The lectins and their resources.-Lviv: Quart, 2005.-554 p.

12. Millan J. L. Alkaline phosphatases structure, substrate specificity and functional relatedness to other members of a large superfamily of enzymes // Purinergic Signal.-2006.-2, N 2.P. 335-341.

13. Bublitz R., Hoppe H., Cumme G. A., Thiele M., Attey A., Horn $A$. Structural study on the carbohydrate moiety of calf intestinal alkaline phosphatase // J. Mass Spectrom.-2001.-36.P. 960-972.

14. Hughes R. C. Glycoproteins.-Moscow: Mir, 1985.-140 p.

UDC 547.963.1:543.9

Received 23.04.09 